\title{
ENVIRONMENTAL SAFETY AS A CHALLENGE FOR MANAGEMENT PRACTICE IN THE BREWING INDUSTRY IN THE ERA OF CRAFT BEER REVOLUTION
}

doi: $\quad 10.2478 /$ czoto-2019-0056

Date of submission of the article to the Editor: $01 / 12 / 2018$

Date of acceptance of the article by the Editor: 24/01/2019

Piotr Tomski ${ }^{1}$ - orcid id: 0000-0002-8561-8445

Anna Dunay ${ }^{2}$ - orcid id: 0000-0003-0254-9243

${ }^{1}$ Czestochowa University of Technology, Poland, piotr.tomski@wz.pcz.pl

${ }^{2}$ Szent István University, Hungary

Abstract: The objective of the present paper is the analysis of the selected problems of environmental safety associated with the operation of craft breweries in the conditions of craft beer revolution. The study is the author's considerations on the selected issues associated with the impact on the natural environment and its protection, based on the review of the literature and the analysis of experiences of the existing craft breweries.

Keywords: craft beer revolution, brewing, beer, malt, wort

\section{INTRODUCTION}

The dynamic development of craft brewing began in the USA and Great Britain in the 1970s and 1980s. Already at that time American people began experimenting with new types of hop, which allowed for manufacturing beer with citrus, exotic and fruity aroma. These new flavors tempting consumers with their diversity as well as the deregulation of the beer market carried out by the President Jimmy Carter laid the foundations for the establishment of microbreweries. At present, microbreweries in the USA control a total of $12 \%$ of the beer market. In Continental Europe, the development of microbreweries began slightly later, since only in the 1990s. The main reason for the occurrence of microbreweries in European countries was the same consumer fatigue associated with a uniform and simultaneously weak flavor of lagers offered by large brewery companies. Along with the development of craft brewing and the occurrence of subsequent microbreweries the concept of "craft beer revolution" was started to be used. "Beer revolution" is undoubtedly the phenomenon in sociological and economical (market) terms (Niemczyk, 2017). The craft beer industry is experiencing a historic period of growth and is a movement on both local and national levels. The growth of small craft breweries over the past half-decade has been epitomized by brewer/owners establishing new breweries with innovative and creative means, often by building in-house smaller brewing systems (Smith et al., 2017). 
As (Garavaglia and Swinnen, 2017) state, in some countries, it is relatively easy to identify the start of the craft revolution. In the United States, (Elzinga et al., 2017) identify 1965, when Fritz Maytag bought the Anchor Brewing Company of San Francisco, as the beginning of the movement. Similarly, van Dijk et al. (2017) date the start of the craft beer revolution in the Netherlands to 1981, when the first new brewery since World War II was launched. The first brewpub in Italy was established in 1988 (Garavaglia, 2017), and in Australia, craft brewing started around 1980 (Sammartino, 2017). "Beer revolution" in Poland began in 2010 with the spectacular return of the "grodziskie" beer, which is an old-fashioned type of beer - the only typically Polish flavor (Poszumska, 2017).

Beer is the most popular alcoholic beverage among Poles. Nearly $73 \%$ of adults, which amounts to almost 23 million consumers, drink it at least a few times a year. In 2012 when, in Poland, there was held European Football Championship, Poles spent 19.5 billion PLN on beer while consuming 3.89 billion liters of this drink, which can be perceived as a type of the culmination of more than twenty years of almost constant growth (KPMG, 2014). In Europe, only Czechs (143I/person), Germans (106I/person) and Austrians (105I/person) drink more beer than Poles (98I/person in 2015) (The Brewers of Europe, 2016). In 2016, breweries in Poland sold 40 million hectoliters of beer. Every fiftieth beer bought in Poland comes from the craft brewery. It is predicted that, over the next 10 years, craft breweries are to amount to $6 \%$ of the domestic market and reach the number of 500 . Therefore, Poland has no chances to catch up with the USA, where currently mini-breweries have the market share of $12 \%$ (Poszumska, 2017). However, already at the stage of growth, the issue requiring attention is the environmental aspects of the operation of craft breweries.

In the craft beer market in Poland, there is more and more capital and more and more modern breweries are being established. The result of the dynamic development of the industry undoubtedly will be the fact that, in the whole area of craft beer manufacture, there will be a real need for the implementation of advanced solutions and business concepts, adapted to modern reality, and management in this branch of industry will be subjected to systematic evolution since, in this industry, as Marek Kamiński - the President of the Polskie Stowarzyszenie Browarów Rzemieślniczych (Polish Association of Craft Breweries) (PSPD, 2018) pinpointed, there will be less fun and more business. Management staff of many breweries will be forced to take a fast course of management and operate successfully in the increasingly competitive market and also satisfy environmental requirements and implement environmental safety management so that enterprises can operate in compliance with the requirements set in the light of the concept of sustainable development (WiśniewskaSałek, 2018).

In the above circumstances, the objective of the present paper is the analysis of the selected problems of environmental safety associated with the operation of craft breweries in the conditions of craft beer revolution. The study is the author's considerations on the selected issues associated with the impact on the natural environment and its protection, based on the review of the literature and the analysis of experiences of the existing craft breweries. 


\section{THE BREWING SECTOR GROWTH IN POLAND AS A RESULT OF THE REVOLUTION}

In accordance with the REGON statistics, taking into account PKD (Polish Classification of Activity) (as of 31.03.2018), in Poland, there are 324 entities of the $C$ section sector (Manufacturing), chapter $11.05 Z$ (Manufacture of beverages manufacture of beer). An upward trend of the sector is also noticeable in Europe (Idasiak, 2018). According to the report - The Brewers of Europe (2017), the largest manufacturer of the brewing industry in the area of Europe is Germany (94 $957 \mathrm{hl}$ ), followed by Great Britain (43 $734 \mathrm{hl}$ ) and Poland (41369 hl). It is estimated that, there are 8490 breweries across Europe, which produced a total of $400168000 \mathrm{hl}$ of beer in 2016, while employing nearly 2300000 people (The Brewers of Europe, 2017).

The brewing industry market in Poland is one of the fastest growing industries, which results from changes in preferences of consumers who choose increasingly weaker alcohols. The good condition of the brewing industry is important for the creation of jobs and economic growth (Kielesińska, 2018). Poland is the third beer manufacturer in Europe whereas the sales of beer generates nearly 10 billion PLN annually to the State budget. More importantly, the brewing industry has significant impact on the economy, which is due to the use of raw materials produced by Polish farmers. Additionally, at least six important branches of industry are connected with brewing, its sales and marketing but one of the major elements is just agriculture (the purchase of hop and brewing grain from Polish crops). The brewing industry, directly and indirectly, provides more than 205 thousand jobs. The most active voivodeships in the field of the brewing industry are: Mazowieckie, Śląskie and Małopolskie.

In order to confirm the development of the Polish craft brewing it is worth analyzing an increase in the number of new breweries in Poland in recent years. The listing for years 2014-2017 is presented in Table 1.

Table 1

Beer premiers and new brewery establishments in Poland in years 2014-2017

\begin{tabular}{|c|c|c|c|c|}
\hline & $\mathbf{2 0 1 4}$ & $\mathbf{2 0 1 5}$ & $\mathbf{2 0 1 6}$ & $\mathbf{2 0 1 7}$ \\
\hline New beers [number] & 513 & 1164 & 1561 & 1655 \\
\hline New beers[growth y/y] & - & $227 \%$ & $134 \%$ & $106 \%$ \\
\hline New breweries & 47 & 57 & 63 & 51 \\
\hline New breweries [growth y/y] & - & $121 \%$ & $110 \%$ & $81 \%$ \\
\hline
\end{tabular}

Source: Own study based on the data by Piwna Zwrotnica (www.zwrotnica.com.pl)

The listing clearly indicates the dynamic growth of the brewing industry development, which is reflected in the form of a significant increase in the number of new craft breweries (218) and new beers (4893) in years 2014-2017.

\section{THE CHALLENGES FOR ENVIRONMENTAL SAFETY MANAGEMENT IN BREWING INDUSTRY}

In the context of the dynamic growth of the brewing industry, it is worth pinpointing that a new construction or development always has an environmental impact, and breweries are no exception. However, craft breweries are keeping a close watch on their impact and are doing what they can to keep their environmental impact as minimal as possible. Many craft breweries have become aware of the footprint that their businesses have on the planet, and they have taken conscious steps to ensure 
the least environmental impact possible (Skelton, 2014). Brewing is a branch of the food industry where there are specific threats significantly affecting the environmental burden of the beer manufacture. Taking into account the extent of the beer manufacture in Poland, the environmental impact of brewing production processes in brewing gain on a significant dimension (Kasprzak, 2012).

Brewing, similar to other production types is a resource intensive procedure. The process consumes large amounts of water, energy and numerous other materials per unit of beer brewed. The precise statistics vary depending on brewery size, technological capability and stance on resource management as well as what is perceived to be the beginning and end of the production cycle (Boden, 2012). So as to provide a basic understanding of why the processes are resource intensive, a brief description of the biotechnology of malting and brewing is outlined below (Hough, 1991): (1) Crushing malted barley to form coarse flour, (2) Adding hot water to the grist, now known as the mash, in order to convert starches to fermentable sugars, (3) Separating the aqueous extract, known as the wort, from the solid material by further application of hot water, (4) Boiling the wort with hops or other additives (5) Cooling the wort to an ideal temperature for yeast growth and fermentation, (6) Fermenting the wort with yeast that produces ethyl alcohol and CO2, (7) Further cooling of the beer for filtration (8) Carbonation of the beer followed by packaging.

The most important factors conditioning the level of the environmental burden, among others, include: production and energy consumption, water consumption and waste water generation, waste generation and other aspects of the environmental burden (among others, acoustic load, olfactory loads, air pollution and accident hazards).

Brewing is the field of food manufacture, requiring relatively high expenditures in relation to the consumption of electricity and heat. The result of power generation is the emissions of the energy type $\left(\mathrm{CO}_{2}, \mathrm{CO}, \mathrm{NO}_{x}, \mathrm{SO}_{2}\right.$ and others), coming both from the local energy source in the brewery (most frequently the boiler room) as well as the sources of industrial energy generation (power stations) (Kunze, 1999).

The most mentioned issue by literature and sustainability reports is energy. There are two main forms of energy which a craft brewery uses; one is natural gas, or other fossil fuels which are used in brewing, packaging, transportation and heating of buildings. The other type of energy is electricity which is used to power all the equipment and buildings (Brewers Association, 2013). Another finding is that craft breweries since they are small businesses, when comparing them to larger breweries, are generally less energy efficient. This is due to a number of factors including economies of scale, load factors and up-to-date production process. Another reason could be that smaller breweries hesitate to make long-term investments to reduce the market risks. Adding to that, "small craft breweries can often sell their beer at higher prices as they do not produce for the mass market. Consumers are willing to spend more money for high quality beer that has been brewed traditionally as well as locally. Therefore, it has not been imperatively necessary to optimize the production process" (Sturm et al., 2013).

Almost all of the sustainability reports and a big part of the literature agrees that water is a main sustainability challenge. Water is the main raw material used in the brewing process and "on average, water makes up about $92 \%$ of beer, with ethanol and extract from raw materials making up the remaining 8\%" (Brewers of Europe, 2012). The amount of water used is mainly affected by the packaging process through its 
washing requirements, the quality of the incoming water and the efficiency of the production process (Sturm et al., 2013).

The listing of the demand for media and area, associated with the brewing process is presented in Table 2.

Table 2

The comparison of raw material consumption with the demand for media and space

\begin{tabular}{|c|c|c|c|c|c|c|c|c|c|}
\hline Efficiency (hl/year) & 500 & 1.000 & 1.500 & 2.500 & 5.000 & 10.000 & 15.000 & 30.000 & 60.000 \\
\hline Efficiency (I/day) & 500 & 600 & 800 & 1.000 & 2.000 & 4.000 & 6.000 & 12.000 & 24.000 \\
\hline $\begin{array}{l}\text { Capacity of the brewing } \\
\text { boiler hl }\end{array}$ & 2,5 & 3 & 4 & 5 & 10 & 20 & 30 & 40 & 60 \\
\hline $\begin{array}{l}\text { The required area } \\
\text { of the brewhouse } \mathrm{m}^{2}\end{array}$ & 10 & 15 & 20 & 20 & 30 & 60 & 80 & 160 & 300 \\
\hline $\begin{array}{l}\text { The required area } \\
\text { of aging } \mathrm{m}^{2}\end{array}$ & 20 & 40 & 50 & 80 & 120 & 240 & 500 & 750 & 1.000 \\
\hline $\begin{array}{l}\text { Total Energy demand } \\
\text { kW }\end{array}$ & 20 & 30 & 40 & 75 & 75 & 120 & 250 & 500 & 800 \\
\hline $\begin{array}{l}\text { Demand for water } \\
\mathrm{m}^{3} / \text { workday }\end{array}$ & ca.2 & ca.5 & ca.5 & ca.5 & ca.10 & ca.20 & ca.30 & ca. 60 & ca.120 \\
\hline Malt (ton/year) & 8 & 16 & 25 & 45 & 90 & 180 & 270 & 540 & 1.080 \\
\hline Hop (kg/year) & 120 & 250 & 400 & 600 & 1.200 & 2.400 & 3.750 & 7.000 & 15.000 \\
\hline Yeast (kg/year) & 40 & 50 & 65 & 75 & 150 & 300 & 300 & 300 & 300 \\
\hline
\end{tabular}

Source: The data by Braumax - brewing equipment manufacturer

\section{ENVIRONMENTAL FRIENDLY ACTIONS OF CRAFT BREWERIES}

In connection with the great impact of the brewing industry on the environment, a range of practices, significantly conditioning the potential for reducing the environmental burden of the beer production, have been developed and are being improved (Kasprzak, 2012). Brewers have come up with a lot of new variations of beer and many of them are also embracing sustainability and environmentally-friendly production methods to prove a decent beer should not necessarily have to cost the earth. More and more breweries are taking sustainability seriously and making real efforts to have as a low impact on the environment as possible. In many countries independent craft breweries are doing their part in creating a greener beer industry. The steps they undertake include simple activities as recycling water or using heat exchanges but also advanced activities can be identified such as building reed bed filtration systems, fitting solar panels, or even building custom designed 'eco' breweries (Hailstone, 2017).

As much as "beer revolution" had its origin in the USA one may observe the intensified activities of American craft breweries oriented to the environmental protection. These practices may constitute the reference point and clue for environmental management, implemented in the Polish craft breweries. The following operations can be indicated as the examples (Deaton, 2017; Upton, 2017):

- solar panels installed, bathrooms fitted with eco-flush toilets which save water, using eco-friendly carpet for the brewery building (Mother Earth Brewing); 
- offices built from wood and electrical parts are reclaimed from the demolition of the prior offices that were in the brewery space (the only items we throw away are the bent nails and drywall), all the wiring reused. Reducing energy output in a unique way. The brite tanks used to hold beer are horizontal submarines that cut down the fall time for the yeast during the conditioning step, saving days in the process which translates to reducing electrical consumption related to the glycol refrigeration units (Little Harpeth Brewing);

- using BrauKon system in the brewhouse, which saves energy during the brewing process by using low evaporation boil. Since it's fully automated, the system can heat the water to precisely $99.9^{\circ} \mathrm{C}$. Once a boil goes to $100^{\circ} \mathrm{C}$ the energy level spikes - so by not going that extra tenth of a degree, energy is saved. Vapor condensers help to recapture the energy by turning the evaporated gas into a liquid that can be re-used. This reduces the evaporation rate to 2 percent, helping save even more energy. The automated system helps during the cleaning process as well, because it uses a "Clean In Place" unit that has pipes going to each tank. It controls the amount of energy, water, and cleaning material used, making sure waste is minimized (Backpocket Brewing);

- looking to alternative energy to help run the brewery, Pennsylvania's first 100 percent wind-powered brewery currently purchases all of its power from a separate wind power provider (Yards Brewing);

- in addition to brewing beer, distilling own spirits. This allows re-using water during both productions, which in turn means less energy used to heat and cool that water. The brewery uses a system that brings cool water from its water source, through its water filter, through the condenser on the still and into the hot liquor tank for the brewery. The end result is $65.6 \mathrm{C}$ water entering hot liquor tank which is then used to mash in during the brewing process; it has effectively eliminated the need to constantly be cooling down hot water for reuse in the cooling of its still and has also done almost all of the needed heating for the water that is used in the brewing process (Coastal Extreme Brewing Co.);

- integrating conservation into every step of production; more than 10,000 solar panels help power the California brewery; another 2,000 supply electricity to the North Carolina facility, as do a pair of microturbines that run on methane captured from the brewery's wastewater treatment plant. Automated sensors turn down lights in the middle of the day when the sun comes pouring through the windows, and advanced brew kettles recycle heat that would otherwise be lost. During fermentation, yeast turns sugars into alcohol and carbon dioxide, which is captured and used to carbonate its beer. Used hops and barley are sold as cattle feed or turned into fertilizer. The final product is packaged in bottles made from recycled glass and shipped in trucks that run on used vegetable oil (Sierra Nevada);

- In Hawaii, where freshwater supplies are limited, using condensation collected from air conditioners to water the habaneros and chives used in small-batch beers (Kona Brewing);

- using spent grain to fuel a steam boiler (Alaskan Brewing);

- sending leftovers to ReGrained, a startup that turns old malt into beer-themed snack bars (Magnolia Brewing and 21st Amendment);

- working with the Arbor Day Foundation to plant trees across hundreds of acres of the Mississippi Alluvial Valley. The trees will soak up carbon dioxide, offsetting 
pollution generated by the brewery's Williamsburg, Brooklyn operation (Brooklyn Brewery);

- replacing one-third of the barley used in a typical brew with bread that would otherwise be wasted. All profits go to charity to support the bigger fight against food waste (Toast Ale);

- using surplus potatoes (which would have otherwise been wasted) to brew (Pieper Beer);

- collaborating with charities like to create new products like "Wasted Beer", brewing with would-be-wasted croissants, pears and brioche (Northern Monk);

- being driven by the mission to make the oceans safer for wildlife - one ring holder at a time. Their six-packs of beer are packaged with biodegradable, edible rings instead of the traditional plastic rings. Closing the production loop further, the rings are made from wheat and barley, which is left over from the process of brewing the beer (Saltwater Brewery in Florida);

- switching all processes to wind energy purchased from the grid (Brooklyn Brewery);

Initiatives in the area of environmental management, implemented so far by Polish craft breweries (Blog Kilka Słów o Piwie, 2014):

- transformation of the brewery into the cultural center, using new technologies and following the patterns of nature - the entire facility uses renewable energy and other innovative solutions. It is planned to invest some of the profit in local ventures, focusing on the protection and promotion of the values of the Bieszczady Mountains. (Ursa Maior);

- modernization of equipment for beer production, which simultaneously is associated with an increase in energy efficiency (SchoKolino 2.0 brewhouse by Kaspar-Shulz) (Pracownia Piwa, Artezan, Gościszewo);

- sale of glasses for beer consumption during beer festivals, which reduces the consumption of disposable plastic cups;

- introduction of own returnable plastic glasses during beer festivals (AleBrowar);

- rental of brewhouses in other breweries by new (contractual) breweries, which contributes to an increase in efficiency of use of the existing breweries;

- manufacture of local products by small breweries; they are brewed using traditional methods with local and natural ingredients utilizing modern technologies, some breweries are certified manufacturers of organic food (Browar Jagiełło).

\section{CONCLUSIONS}

Environmental problems are typically complex, uncertain, multi-scale and affect multiple actors and agencies. Continued growth in the craft brewing industry, coupled with natural resource limitations suggests the need for implementation of sustainable initiatives on a wide scale (Boden, 2012). Due to increasingly demanding environmental legislation, organizations nowadays are required to seriously take into consideration both environmental aspects associated with the production chain itself and the life cycles of their products (Rebelo et al., 2014). They are forced to implement suitable environmental management systems to reduce wastes and to protect environment. This is a particularly important issue for small and medium-sized organizations (SMEs), which are considered to make up the vast majority of business in Europe (Zorpas, 2010). 
The environmental management literature suggests that enterprises can improve their competitive position and reduce the negative effects of their activities on the natural environment by implementing certain "best practices" of environmental management. Best practices in the area of environmental management can also contribute to competitive advantage in product markets (Christmann, 2000). The analysis of issues related to Cleaner Production (CP) has indicated that utilizing CP not only effectively contributes to the environmental protection by reducing or minimizing waste streams, but is also profitable because it results in increased profitability, productivity increasing the efficiency and competitiveness of industries. The ideal of a CP strategy is waste-free production. In the current economic and technological situation enterprises can only search for various ways of waste management and use closed cycles of supply streams, e.g. water. This often leads to the integration of production lines, where waste from one line is used to supply material or energy to another production line (Rosak-Szyrocka, 2018).

An increase in the interest in environmental issues of the operation of enterprises in recent years results from their changing social role. Two thirds of the population consider the environmental protection as a social obligation of each organization (Ejdys et al., 2012). It should also be pointed out that it is necessary to propagate the principles of sustainable development in all areas of life, and due to the interdisciplinary character of this concept, it should also be considered in the field of management and organizational education (Lemańska-Majdzik, 2018). In the area of the operation of craft breweries, a special concern for the environment seems to be quite obvious since craft nature of the production process explicitly refers to and evokes associations with environmental safety and clean production generating natural products. Therefore, it is obvious that focusing on environmental issues should be considered as the task set to management staff of craft breweries, whose dynamic growth and business objectives ought not to cover environmental safety. American craft breweries can be considered as reference points and guideposts directing Polish craft breweries to taking actions in the area of environmental protection management. The research area concerning environmental management in craft breweries seems to be interesting and generating so many cognitive gaps, particularly in the context of the dynamic development of the industry and opportunities for arising new problems and challenges. At the same time, the issue seems to be open and important both from the point of view of theory and practice of management of microenterprises which undoubtedly craft breweries are.

\section{REFERENCES}

Beer Statistics 2016 edition, The Brewers of Europe, November 2016, Brussels 2016.

Blog Kilka Słów o Piwie. https://kilkaslowopiwie.com/2014/11/27/male-browary-tezdbaja-o-srodowisko/ (20.10.2018)

Boden, M., 2012. Achieving Sustainability In The Craft Brewing Industry. University of Nebraska-Lincoln. Environmental Studies Undergraduate Student Theses. http://digitalcommons.unl.edu/envstudtheses/89 (accessed on: 10.11.2018)

Braumax. https://www.braumax.pl/twoj-browar (accessed on: 20.10.2018)

Christmann, P., 2000. Effects of "best practices" of environmental management on cost advantage: The role of complementary assets. Academy of Management Journal, 43(4), 663-680. 
DOI: $10.2307 / 1556360$ https://www.jstor.org/stable/1556360.

Deaton, J., 2017. America's craft breweries are on an environmental crusade. Popular Science, August 16, 2017. https://www.popsci.com/craft-brewer-conservationclimate-change\#page-2 (17.10.2018)

Dijk van, M., Kroezen J., Slob B., 2017. From Pilsner Desert to Craft Beer Oasis: The Rise of Craft Brewing in the Netherlands. [in:] C. Garavaglia and J. Swinnen (eds.), Economic Perspectives on Craft Beer: A Revolution in the Global Beer Industry, Palgrave Macmillan, London.

Ejdys, J., Kobylińska, U., Lulewicz-Sas, A., 2012. Zintegrowane systemy zarządzania jakością, środowiskiem i bezpieczeństwem pracy. Oficyna Wydawnicza Politechniki Białostockiej, Białystok.

Elzinga, K.G., Tremblay C.H., Tremblay V.J., 2017. Craft Beer in the United States: Strategic Connections to Macro and European Brewers. [in:] C. Garavaglia and J. Swinnen (eds.), Economic Perspectives on Craft Beer: A Revolution in the Global Beer Industry, Palgrave Macmillan, London.

Garavaglia, C., 2017. Birth and Diffusion of Craft Breweries in Italy. [in:] C. Garavaglia and J. Swinnen (eds.), Economic Perspectives on Craft Beer: A Revolution in the Global Beer Industry, Palgrave Macmillan, London.

Garavaglia, C., Swinnen, J., 2017. The craft beer revolution: An international perspective. Choices, 32(3), 1-8.

Hailstone, J., 2017. Craft beer's war against waste. 3rd August 2017, Environment Journal. https://environmentjournal.online/articles/craft-beer-waging-war-waste/ (17.10.2018)

Hough, J.S., 1991. The biotechnology of malting and brewing. Cambridge University Press, Cambridge.

Idasiak, M., 2018. Społeczna odpowiedzialność biznesu w strategii zarządzania przedsiębiorstw przemysłu piwowarskiego w Polsce. Zeszyty Naukowe Politechniki Częstochowskiej. Zarządzanie, 29, 278-289. DOI 10.17512/znpcz.2018.1.24

Kasprzak, J., 2012. Środowiskowe uwarunkowania gospodarki recyrkulacyjnej $w$ przemyśle piwowarskim. Inżynieria i Aparatura Chemiczna, (5), 229-230, bwmeta1.element.baztech-article-BPP4-0001-0192

Kielesińska, A., 2018. Food quality and safety in the brewing industry, Production Engineering Archives, 20, 16-19. DOI: 10.30657/pea.2018.20.04

Kunze, W., 1999. Technologia piwa i słodu. Wyd.VIII. Piwo-chmiel/VLB, Berlin.

Lemańska-Majdzik, A., 2018. Flexible Activities of the Organization in Implementation of the Sustainable Development Principles in Selected Areas of the Organizations. European Journal of Sustainable Development, Vol. 7, No. 4, 212-222. Doi: 10.14207/ejsd.2018.v7n4p212.

Niemczyk, L., 2017. Mikrobrowary jako element rozwoju regionalnego w Polsce i na Podkarpaciu. Przedsiębiorstwo i Region, 9, 49-57. DOI 10.15584/pir.2017.9.6

Poszumska, U., 2017. Branża piwna. Nawarz sobie (i innym) dobrego złotego napoju. Marketing i biznes, 12.05.2017. https://marketingibiznes.pl/biznes/branza-piwna/ (12.10.2018)

PSPD, 2018. Po pierwsze - integracja. Piwowar. Kwartalnik Polskiego Stowarzyszenia Piwowarów Domowych, 27, 2018. 
Rebelo, M.F., Santos, G., Silva, R., 2014. A generic model for integration of quality, environment and safety management systems. The TQM Journal, 26(2), 143159. DOI 10.1108/TQM-08-2012-0055

Rosak-Szyrocka, J., 2018. Quality improvement in Cleaner Production aspect. MATEC Web Conference, Vol. 18303013 (2018), $12^{\text {th }}$ International Conference Quality Production Improvement - QPI 2018. https://doi.org/10.1051/matecconf/201818303013.

Rynek napojów alkoholowych w Polsce, 2014. KPMG w Polsce.

Sammartino, A., 2017. Craft Brewing in Australia, 1979-2015. [in:] C. Garavaglia and J. Swinnen (eds.), Economic Perspectives on Craft Beer: A Revolution in the Global Beer Industry, Palgrave Macmillan, London.

Skelton, A., 2014. Brewing for the Planet. Craftbeer.com, April 22, 2014, https://www.craftbeer.com/craft-beer-muses/brewing-for-the-planet (17.10.2018)

Smith, S., Farrish, J., McCarroll, M., Huseman, E., 2017. Examining the Craft Brew Industry: Identifying Research Needs. International Journal of Hospitality Beverage Management, 1(1), Article 3. https://scholars.unh.edu/ijhbm/vol1/iss1/3 (15.11.2018)

Sturm, B., Hugenschmidt S., Joyce S., Hofacker W., Roskilly A.P., 2013. Opportunities and barriers for efficient energy use in a medium-sized brewery. Applied Thermal Engineering, 397-404.

DOI: 10.1016/j.applthermaleng.2012.05.006

The Brewers of Europe, 2017. Beer Statistics. 2017 Edition, December, Brussels. https://www.brewersofeurope.org/uploads/mycmsfiles/documents/publications/20 17/Statistics-201712-001.pdf (accessed on: 15.04.2017)

Upton, E., 2017. Beer Today, Beer Tomorrow - The Journey to a Sustainable Industry. Briefing Corporate Citizenship, March 09, 2017. https://ccbriefing.corporate-citizenship.com/2017/03/09/beer-today-beertomorrow-journey-sustainable-industry/ (17.10.2018)

Wiśniewska-Sałek, A., 2018. Sustainable Development in Accordance With the Concept of Industry 4.0 on the Example of the Furniture Industry. MATEC Web Conf. 18304005 (2018), 12 $2^{\text {th }}$ International Conference Quality Production Improvement - QPI 2018. DOI: 10.1051/matecconf/201818304005

Zorpas, A., 2010. Environmental management systems as sustainable tools in the way of life for the SMEs and VSMEs. Bioresource Technology, Vol. 101 No. 6, 1544-1557. doi: 10.1016/j.biortech.2009.10.022 